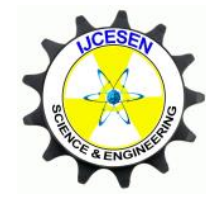

Copyright $\mathbb{C}$ IJCESEN
International Journal of Computational and

Experimental $\boldsymbol{S}$ cience and Engineering

(IJCESEN)

Vol. 4-No:1 (2018.) pp.6-10.

http://dergipark.gov.tr/ijcesen

Research Article

\title{
A Fuzzy Hybrid Decision Model for Renewable Energy Sources Selection
}

\author{
Merve CENGIZ TOKLU ${ }^{1 *}$, Harun TAŞKIN ${ }^{2}$ \\ ${ }^{1}$ Sakarya University, Department of Industrial Engineering, Sakarya, Turkey \\ ${ }^{2}$ Sakarya University, Department of Industrial Engineering, Sakarya, Turkey \\ * Corresponding Author : mtoklu@ sakarya.edu.tr \\ ORCID: 0000-0001-9609-5136
}

(First received 20 February 2018 and in final form 6 March 2018)

Keywords
Renewable Energy
Fuzzy Logic
AHP
TOPSIS

Keywords

Renewable Energy

AHP

TOPSIS

\begin{abstract}
The energy needs of the world have been increasing from year on year. Fossil fuels, including coal, oil and natural gas, are currently the world's fundamental energy source. Non-renewable energy sources threaten the world as a result of many problems such as air, water and environmental pollution. For this reason, countries tend towards renewable energy sources The selection of the most appropriate renewable energy sources is crucial for improving of countries. Different criteria should be considered simultaneously in the selection of renewable energy sources. In this study, a hybrid approach involving Fuzzy AHP and Fuzzy TOPSIS is suggested to select renewable energy sources. Proposed approach is presented with a case study for empirical evidence. In the case study, alternative energy sources were evaluated under four main criteria: (1) Technical, (2) Economical, (3) Environmental, (4) Social and Political. As a result of the 2 -stage evaluation method including multi-criteria decision making techniques, wind energy was determined as the most suitable alternative.
\end{abstract}

\section{Introduction}

Energy is a mandatory input for the social and economic development of countries. The energy needs of the world have been increasing from day to day due to growing population, developing industry and increasing standards of living [1]. The main energy sources which are currently used are fossil fuels. While meeting energy needs, it is also necessary to reduce the damage to the environment. For this reason, renewable energy (RE) sources become more of an issue. Non-renewable energy sources threaten the world as a result of many problems such as air, water and environmental pollution. For this reason, renewable energy sources are a significant investment for the future.

Turkey has the highest rate of growing energy demand among Organization for Economic Cooperation and Development countries over the last 15 years (Republic of Turkey Ministry of Foreign Affairs). Alternative energy sources are crucial to reducing energy import dependency especially for countries with increasing energy demand. The investment costs of renewable energy sources are usually high. For this reason, selection of RE sources is a strategic decision and it is necessary to make the right decision at the first time. Investment cost is not the only factor affecting this decision. Effect on the environment, social effect, operating costs, and technological feasibility should be examined. RE source selection problem are frequently encountered in the literature [3-18]. In this study a selection model for RE by using Fuzzy AHP and Fuzzy TOPSIS methods that are often used in the literature among multi-criteria. Proposed approach is presented with a case study.

\section{Methods}

In this study AHP and TOPSIS methods with Fuzzy theory [19] are used. These methods are explained below.

\subsection{Fuzzy AHP}

Analytic Hierarchy Process (AHP) [20] is one of the most used multi-criteria decision-making (MCDM) technique for selection, evaluation, and 
prioritization alternatives and/or criteria. In the AHP method the priorities are obtained from the results of the pairwise comparisons carried out by the experts (decision makers). With this methodology, both objective and subjective criteria can be evaluated at the same time. Main steps of the methodology are; (1) Define the problem or goal. (2) Establish evaluation criteria including all actors involved in the problem. (3) Structure the problem in a hierarchy including goal, criteria, sub-criteria, and alternatives. (4) Follow the AHP steps and choose the most appropriate one. In the study, Fuzzy AHP was used because the decision makers' (DMs') answers include linguistic expressions. There are several fuzzy form of AHP methods in the literature. In this study, Chang's extent analysis method [21] is used. Since this method is described in detail in many studies in the literature, it is not explained again in this study.

\subsection{Fuzzy TOPSIS}

The Technique for Order of Preference by Similarity to Ideal Solution (TOPSIS) is also a MCDM method that was proposed by Hwang and Yoon (1981). Later, in 2000 and 2006 Chen and Chen et al. proposed extended the TOPSIS method for fuzzy data [22]-[23]. Their model is explained below.

Step 1. Arrange the problem in matrix format as follows;

$\widetilde{D}=\left(\begin{array}{cccc}\tilde{X}_{11} & \tilde{X}_{12} & \ldots & \tilde{X}_{1 m} \\ \tilde{X}_{21} & \tilde{X}_{22} & \ldots & \tilde{X}_{2 m} \\ \vdots & \vdots & \ddots & \vdots \\ \tilde{X}_{m 1} & \tilde{X}_{m 2} & \ldots & \tilde{X}_{m m}\end{array}\right)$

$\widetilde{W}=\left[\widetilde{w}_{1}, \widetilde{w}_{2}, \widetilde{w}_{3}, \ldots \widetilde{w}_{n}\right]$, where $\widetilde{X}_{i j}$ and $\widetilde{w}_{j}$ are the average rating and the importance weight of the all DMs.

Step 2. Calculate the fuzzy decision matrix $(\tilde{R})$ by using the linear-scale transformation [22].

$$
\begin{aligned}
\tilde{R} & =\left[\tilde{r}_{i j}\right]_{m x n} \\
\tilde{r}_{i j} & =\left(\frac{a_{i j}}{c_{j}^{*}}, \frac{b_{i j}}{c_{j}^{*}}, \frac{c_{i j}}{c_{j}^{*}}\right) \quad, \quad \tilde{r}_{i j}=\left(\frac{a_{j}^{-}}{c_{i j}}, \frac{a_{j}^{-}}{b_{i j}}, \frac{a_{j}^{-}}{a_{i j}}\right), J \in \\
J & \in B \\
C_{j}^{*} & =\max _{i} c_{i j} \text { if } j \in B \\
C_{j}^{*} & =\min _{i} a_{i j} \text { if } j \in C
\end{aligned}
$$

Step 3. Calculate the weighted normalized decision matrix as;

$$
\begin{aligned}
\tilde{V} & =\left[\tilde{v}_{i j}\right]_{m x n} \begin{array}{r}
i=1,2 \ldots . m J \\
=1,2, \ldots . n
\end{array} \\
\tilde{v}_{i j} & =\tilde{r}_{i j}(.) \widetilde{w}_{j}
\end{aligned}
$$

Step 4. Determine the fuzzy positive ideal solution (FPIS) and fuzzy negative ideal solution (FNIS) [23] as;

$\operatorname{FPIS}\left(\mathrm{P}^{*}\right)=\left(\tilde{V}_{1}^{*}, \tilde{V}_{2}^{*}, \tilde{V}_{3}^{*} \ldots \tilde{V}_{n}^{*}\right)$ and

$\operatorname{FNIS}\left(\mathrm{P}^{-}\right)=\left(\tilde{V}_{1}^{-}, \tilde{V}_{2}^{-}, \tilde{V}_{3}^{-} \ldots \tilde{V}_{n}^{-}\right) \quad$ where $\quad \tilde{V}_{j}^{*}=$ $\max _{i}\left\{V_{i j 3}\right\}$ and

$\tilde{V}_{j}^{-}=\min _{i}\left\{V_{i j 1}\right\} ; \mathrm{i}=1,2, . . \mathrm{m}$ and $\mathrm{j}=1,2, . . \mathrm{n}$

Step 5. Calculate the distance of each alternative from FPIS and FNIS as;

$$
\begin{aligned}
& d_{i}^{*}=\sum_{j=1}^{n} d_{v}\left(\tilde{v}_{i j} v_{j}^{*}\right) ; \mathrm{i}=1,2,3 \ldots \mathrm{m} \\
& d_{i}^{-}=\sum_{j=1}^{n} d_{v}\left(\tilde{v}_{i j} v_{j}^{-}\right) ; \mathrm{i}=1,2,3 \ldots \mathrm{m}
\end{aligned}
$$

Step 6. Calculate the closeness coefficient $\left(\mathrm{CC}_{\mathrm{i}}\right)$ [22] as;

$$
\mathrm{CC}_{\mathrm{i}}=\frac{d_{i}^{-}}{d_{i}^{-}+d_{i}^{+}} \mathrm{i}=1,2,3 \ldots \mathrm{m}
$$

Finally, sort the alternatives by $\mathrm{CC}_{\mathrm{i}}$ value and select the alternative with the highest $\mathrm{CC}_{\mathrm{i}}$ value.

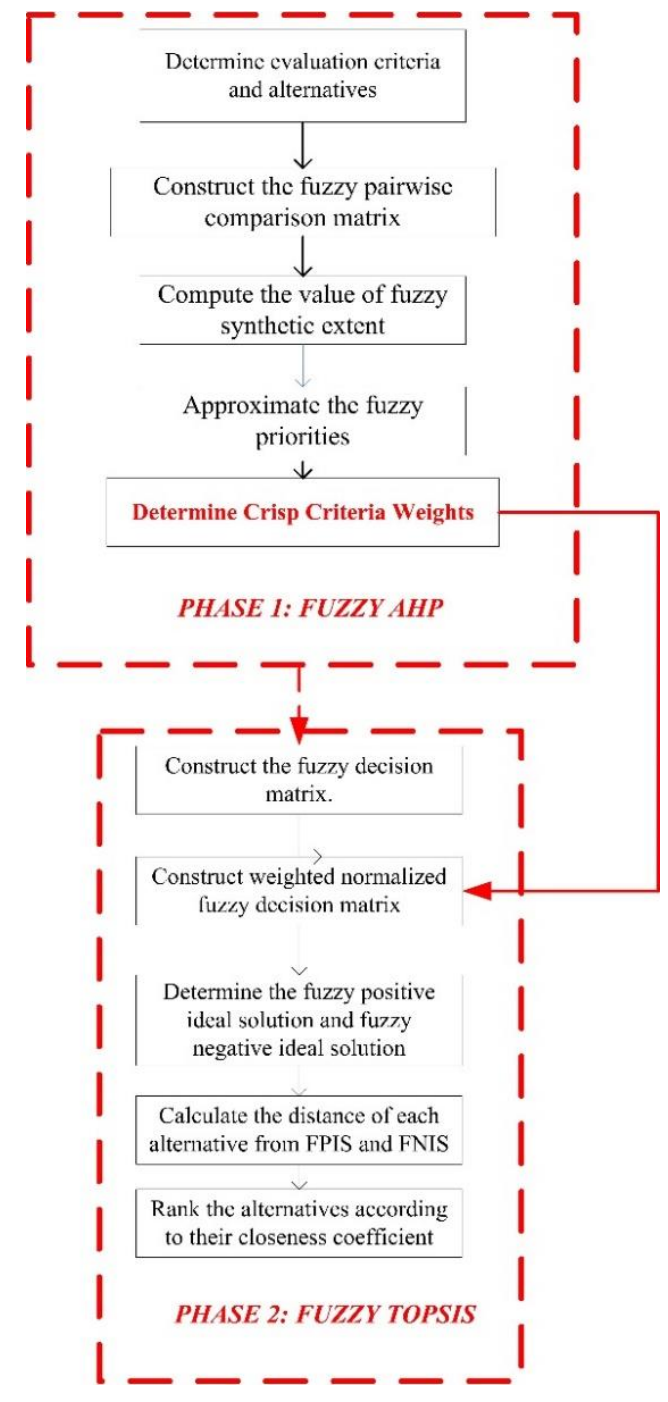

Figure 1. Phases of proposed model 


\section{An Application: Renewable Energy Source Selection for Turkey}

In this study, the proposed model includes 2 main phases. The first phase is about identifying the criteria weights by using fuzzy AHP method and the second phase is about selecting the RE source with fuzzy TOPSIS method (Figure 1). MCDM techniques need pairwise comparisons to evaluate the criteria set and alternatives. Pairwise comparisons are performed by DMs. The evaluation criteria of the proposed model were determined based on the most commonly used criteria in Table 1 and DMs' opinions. Afterwards, local and global weights of evaluation criteria were calculated by applying fuzzy AHP steps. Table 2 represents the evaluation criteria of the proposed model and their local and global weights.

After the local and global weights were determined, the steps of the fuzzy TOPSIS method were applied (Eq.1-5) to select the most appropriate source between alternatives. Table 3 gives the final results of the RE source selection problem.

Table 1. RE Sources Evaluation Criteria in the Literature(*Used in proposed model)

\begin{tabular}{|c|c|c|}
\hline Criteria & Sub-Criteria & Ref \\
\hline \multirow{8}{*}{ Technical } & Energy Production Capacity & {$[14][24]$} \\
\hline & Technological Maturity* & {$[14][18][25][15]$} \\
\hline & Reliability* & {$[14][17][18][25][24]$} \\
\hline & \begin{tabular}{|l|} 
Safety \\
\end{tabular} & {$[14][18]$} \\
\hline & \begin{tabular}{|l|l|} 
Efficiency* \\
\end{tabular} & {$[17][13][16][25][15][24]$} \\
\hline & Exergy Efficiency & {$[17]$} \\
\hline & Accident Risk and effects & {$[16]$} \\
\hline & Availability of sources & {$[13][18]$} \\
\hline \multirow{7}{*}{ Economical } & Investment Cost* & {$[14][17][26][18][16][25][24]$} \\
\hline & Operation and Maintenance Cost* & {$[14][17][18][16]$} \\
\hline & R\&D Cost & {$[18]$} \\
\hline & Service life & [14] \\
\hline & Payback Period & {$[14]$} \\
\hline & Source potential & {$[15]$} \\
\hline & Return on Investment* & [17] [18] \\
\hline \multirow{5}{*}{ Environmental } & Environmental Impact on Ecosystem & {$[14][18][15][24]$} \\
\hline & $\mathrm{CO}_{2}$ Emission* & {$[14][17][25][15][24]$} \\
\hline & $\mathrm{No}_{\mathrm{x}}$ emission* & [17] [25] \\
\hline & GHGs Greenhouse emissions & {$[13][18]$} \\
\hline & Land use requirement* & {$[17][18][25][15]$} \\
\hline \multirow{3}{*}{ Social } & Social Benefits & {$[14][17]$} \\
\hline & Social Acceptability* & [14] [17] [15] [24] \\
\hline & \begin{tabular}{|l|} 
Job creation* \\
\end{tabular} & {$[17][26][25][15][24]$} \\
\hline \multirow{4}{*}{ Political } & Foreign dependency & {$[18]$} \\
\hline & Compatibility with political legislative situation & {$[18]$} \\
\hline & Public policy and financial support & {$[18]$} \\
\hline & Alignment with the country's strategic objectives* & \\
\hline
\end{tabular}

Table 2. Weights of the Evaluation Criteria of the Proposed Model

\begin{tabular}{|c|c|c|c|c|}
\hline Aspect & $\begin{array}{l}\text { Local } \\
\text { weights }\end{array}$ & Sub- Criteria & \begin{tabular}{|l} 
Local \\
Weights
\end{tabular} & \begin{tabular}{|l} 
Global \\
Weights
\end{tabular} \\
\hline \multirow{3}{*}{ Technical } & \multirow{3}{*}{0,423} & Technological structure & 0,363 & 0,154 \\
\hline & & Reliability & 0,192 & 0,081 \\
\hline & & Efficiency & 0,445 & 0,188 \\
\hline \multirow{3}{*}{ Economical } & \multirow{3}{*}{0,255} & Investment Cost & 0,375 & 0,096 \\
\hline & & Operation and Maintenance Cost & 0,051 & 0,013 \\
\hline & & Return on Investment & 0,573 & 0,146 \\
\hline \multirow{3}{*}{ Environmental } & \multirow{3}{*}{0,255} & Land use requirement & 0,182 & 0,046 \\
\hline & & $\mathrm{CO}_{2}$ Emission & 0,409 & 0,104 \\
\hline & & Nox emission & 0,409 & 0,104 \\
\hline \multirow{3}{*}{$\begin{array}{l}\text { Social and } \\
\text { Political }\end{array}$} & \multirow{3}{*}{0,067} & Social Acceptability & 0,375 & 0,025 \\
\hline & & Job creation & 0,051 & 0,003 \\
\hline & & $\begin{array}{l}\text { Alignment with the country's strategic } \\
\text { objectives }\end{array}$ & 0,573 & 0,039 \\
\hline
\end{tabular}


Table 3. Computations of $d^{*}, d^{-}$and $C C_{i}$

\begin{tabular}{|l|l|l|l|l|}
\hline RE Sources & $\mathbf{d}^{*}$ & $\mathbf{d}^{-}$ & $\mathbf{C C}_{\mathbf{i}}$ & Rank \\
\hline Hydropower & 0,39 & 0,26 & 0,405 & 3 \\
\hline Solar & 0,25 & 0,40 & 0,618 & 2 \\
\hline Wind & $\mathbf{0 , 1 7}$ & $\mathbf{0 , 4 7}$ & $\mathbf{0 , 7 3 9}$ & $\mathbf{1}$ \\
\hline Nuclear & 0,44 & 0,23 & 0,343 & 4 \\
\hline Biomass & 0,47 & 0,19 & 0,294 & 6 \\
\hline Geothermal & 0,44 & 0,21 & 0,325 & 5 \\
\hline
\end{tabular}

\section{Results and Conclusions}

The purpose of this study is to select most appropriate RE alternative by using fuzzy AHP and fuzzy TOPSIS methods. Evaluation of the RE alternatives involves subjective and qualitative judgments. For this reason, energy source selection problem is a MCDM problem [17]. In Turkey, as the end of 2016, the installed capacity of the wind energy plants in operation is 5.751,3 MW (Republic of Turkey Ministry of Energy and Natural Resources). As a result of this study, wind energy was determined as the most suitable energy for Turkey (Table 3). However, changing the priorities of the criteria in the model and/or adding new alternatives to the model may change this ranking. In addition, changes in the expression of DMs may also change the result. For this reason, sensitivity analysis can be realized in the future study. The proposed model can be re-evaluated by adding hybrid alternatives. Different hybrid system that can be achieved using two or more different energy sources [28]. Alternatives can also be tested with a simulation model.

\section{Acknowledgement}

This paper presented in " 4 rd International Conference on Computational and Experimental Science and Engineering (ICCESEN-2017)"

\section{References}

[1] Kahraman C. and I. Kaya, "A fuzzy multicriteria methodology for selection among energy alternatives," Expert Syst. Appl., vol. 37, no. 9 (2010), pp. 6270-6281.

[2] "Republic of Turkey Ministry of Foreign Affairs."Available:http://www.mfa.gov.tr/turkeysenergy-strategy.en.mfa. [Accessed: 01-Oct-2017].

[3] Evrendilek F. and C. Ertekin, "Assessing the potential of renewable energy sources in Turkey," Renew. Energy, vol. 28, no. 15 (2003), pp. 2303-2315.

[4] Polatidis H., D. A. Haralambopoulos, G. Munda, and R. Vreeker, "Selecting an Appropriate Multi-Criteria Decision Analysis Technique for Renewable Energy Planning," Energy Sources, Part B Econ. Planning, Policy, vol. 1, no. 2 (2006), pp. 181-193.

[5] Bilgen S., S. Keleş, A. Kaygusuz, A. Sarı, and K. Kaygusuz, "Global warming and renewable energy sources for sustainable development: A case study in Turkey," Renew. Sustain. Energy Rev., vol. 12, no. 2 (2008), pp. 372-396.

[6] Kahraman C., I. Kaya, and S. Cebi, "A comparative analysis for multiattribute selection among renewable energy alternatives using fuzzy axiomatic design and fuzzy analytic hierarchy process," Energy, vol. 34, no. 10 (2009), pp. 1603-1616.

[7] Evans A., V. Strezov, and T. J. Evans, “Assessment of sustainability indicators for renewable energy technologies," Renew. Sustain. Energy Rev., vol. 13, no. 5 (2009), pp. 1082-1088.

[8] Wang B., D. F. Kocaoglu, T. U. Daim, and J. Yang, "A decision model for energy resource selection in China," Energy Policy, vol. 38, no. 11 (2010), pp. 7130-7141.

[9] Kaya T. and C. Kahraman, "Multicriteria renewable energy planning using an integrated fuzzy VIKOR \& AHP methodology: The case of Istanbul," Energy, vol. 35, no. 6 (2010), pp. 2517-2527.

[10] Heo E., J. Kim, and K.-J. Boo, "Analysis of the assessment factors for renewable energy dissemination program evaluation using fuzzy AHP," Renew. Sustain. Energy Rev., vol. 14, no. 8 (2010), pp. 2214-2220.

[11] San Cristóbal J.R., "Multi-criteria decision-making in the selection of a renewable energy project in spain: The Vikor method," Renew. Energy, vol. 36, no. 2 (2011), pp. 498-502.

[12] Kaya T. and C. Kahraman, "Multicriteria decision making in energy planning using a modified fuzzy TOPSIS methodology," Expert Syst. Appl., vol. 38, no. 6 (2011), pp. 6577-6585.

[13] Boran F.E., K. Boran, and T. Menlik, "The Evaluation of Renewable Energy Technologies for Electricity Generation in Turkey Using Intuitionistic Fuzzy TOPSIS," Energy Sources, Part B Econ. Planning, Policy, vol. 7, no. 1 (2012), pp. 81-90.

[14] Demirtas O., "Evaluating the Best Renewable Energy Technology for Sustainable Energy Planning," Int. J. Energy Econ. Policy, vol. 3(2013), pp. 23-33.

[15] Ahmad S. and R. M. Tahar, "Selection of renewable energy sources for sustainable development of electricity generation system using analytic hierarchy process: A case of Malaysia," Renew. Energy, vol. 63 (2014), pp. 458-466.

[16] Çelikbilek Y. and F. Tüysüz, "An integrated grey based multi-criteria decision making approach for the evaluation of renewable energy sources," Energy, vol. 115(2016), pp. 1246-1258.

[17] Büyüközkan G. and S. Güleryüz, "Fuzzy Multi Criteria Decision Making Approach for Evaluating Sustainable Energy Technology Alternatives," vol. 1 (2016), pp. 1-6.

[18] Büyüközkan G. and S. Güleryüz, "An integrated DEMATEL-ANP approach for renewable energy resources selection in Turkey," Int. J. Prod. Econ., vol. 182 (2016), pp. 435-448.

[19] L. A. Zadeh, "Fuzzy sets," Inf. Control, vol. 8, no. 3 (1965), pp. 338-353.

[20] Saaty T.L., The analytic hierarchy process. New York, USA: McGraw-Hill, 1980. 
[21] Chang D.-Y., "Applications of the extent analysis method on fuzzy AHP," Eur. J. Oper. Res., vol. 95, no. 3, pp. 649-655, 1996.

[22] Chen C.-T., "Extensions of the TOPSIS for group decision-making under fuzzy environment," Fuzzy Sets Syst., vol. 114, no. 1 (2000), pp. 1-9.

[23] Chen C.-T., C.-T. Lin, and S.-F. Huang, "A fuzzy approach for supplier evaluation and selection in supply chain management," Int. J. Prod. Econ., vol. 102, no. 2 (2006), pp. 289-301.

[24] Baris K. and S. Kucukali, "Availibility of renewable energy sources in Turkey: Current situation, potential, government policies and the EU perspective," Energy Policy, vol. 42 (2012), pp. 377-391.

[25] Erdogan M. and I. Kaya, "An integrated multicriteria decision-making methodology based on type-2 fuzzy sets for selection among energy alternatives in Turkey," Iran. J. Fuzzy Syst., vol. 12, no. 1 (2015), pp. 1-25.

[26] Büyüközkan G. and Y. Karabulut, "Energy project performance evaluation with sustainability perspective," Energy, vol. 119 (2017), pp. 549-560.

[27] "Republic of Turkey Ministry of Energy and Natural Resources,"http://www.mfa.gov.tr. Available:http://www.enerji.gov.tr/enUS/Pages/Wi nd. [Accessed: 01-Oct-2017].

[28] Jadallah A. A., D. Y. Mahmood, Z. Er, and Z. A. Abdulqaedr, "Hybridization of solar/wind energy system for power generation in rural aeras," Acta Phys. Pol. A, vol. 130, no. 1 (2016), pp. 434-437. 